\title{
MaGnET: a software tool for integrated visualisation of functional genomic data relating to the malaria parasite Joanna L Sharman* and Dietlind L Gerloff
}

\author{
Address: Institute of Structural and Molecular Biology, University of Edinburgh, Edinburgh, EH9 3JR, UK \\ Email: Joanna L Sharman* - J.L.Sharman@sms.ed.ac.uk \\ * Corresponding author
}

from BioSysBio 2007: Systems Biology, Bioinformatics and Synthetic Biology

Manchester, UK. II-13 January 2007

Published: 8 May 2007

BMC Systems Biology 2007, I(SuppI I):P32 doi:I0.I 186/1752-0509-I-SI-P32

This abstract is available from: http://www.biomedcentral.com/I752-0509/I?issue=SI

(c) 2007 Sharman and Gerloff; licensee BioMed Central Ltd.

\section{Background}

With the emergence of varied types of functional genomic data comes a need for effective tools that allow biologists (and bioinformaticians) to explore these data. The goal of exploration/browsing-style analyses will typically be to derive clues towards the function of thus far uncharacterised gene products, and to formulate experimentally testable hypotheses. Graphic interfaces to individual data sets (e.g. genome browsers) are obviously beneficial in this endeavour. However, effective visual data exploration requires also that interfaces to different functional genomic data are integrated and that the user can carry forward a selected group of genes (not merely one at a time) across a variety of data sets. Non-expert users especially benefit from workbench-like tools offering access to the data in this way. Still, only very few of the contemporary publicly available software seem to have implemented such functionality.

Previous work in our group has yielded an integrated visualisation tool for the model organism Saccharomyces cerevisiae [1]. YETI (Yeast Exploration Tool Integrator) is a prototype light-weight JAVA application and was motivated by the observation that selective visualization can often alleviate the sensation of "data overload" that is commonly experienced by scientists seeking to derive new hypotheses from functional genomic data. Here we present a similar development for the malaria-causing parasite Plasmodium falciparum: the Malaria Genome Exploration Tool (MaGnET).

\section{Results}

MaGnET consists of a JAVA program for visualisation with a MySQL database for data storage. Currently implemented visualisation sections are: a Genome section displaying chromosomal location of predicted ORFs and genomic features; a Proteome section for viewing proteinprotein interaction data and protein 3-D structures; an Analysis section providing an interface to the database, facilitating keyword searches and allowing complex queries. A Transcriptome section for viewing gene expression is under development. Emphasis has been placed on only incorporating data into MaGnET that is expected to be at least of reasonable quality. For example, the careful filtering of comparative models allows us to include predicted protein structures alongside the few experimental structures that are currently known.

The existence of YETI has facilitated the design and implementation of the MaGnET program. However, the singleorganism focus of these tools required careful consideration of the specific needs of each user community and the differences in availability of functional genomic data for $P$. falciparum compared with yeast. For example, $P$. falciparum genome annotation remains scarce, which is reflected in the paucity of GO (Gene Ontology) categories assigned to the genes.

\section{Data sourcesand availability}

1. Chromosome/gene annotation and GO (Gene Ontology) [2]. 
2. Experimental protein structures and comparative structural models [3].

3. Protein-protein interactions (large-scale yeast 2-hybrid study) [4].

MaGnET is available online at http://www.magnetweb.co.uk.

\section{Acknowledgements}

The project is funded by an MRC Bioinformatics Studentship.

\section{References}

I. Orton RJ, Sellers WI, Gerloff DL: YETI: Yeast Exploration Tool Integrator. Bioinformatics 2004, 20:284-285.

2. Bahl A, Brunk B, Crabtree J, Fraunholz MJ, Gajria B, Grant GR, Ginsburg H, Gupta D, Kissinger JC, Labo P, et al.: PlasmoDB: the Plasmodium genome resource. A database integrating experimental and computational data. Nucleic Acids Res 2003, 3 I:2I $2-2 \mid 5$.

3. Pieper U, Eswar N, Davis FP, Braberg H, Madhusudhan MS, Rossi A, Marti-Renom M, Karchin R, Webb BM, Eramian D, et al.: MODBASE: a database of annotated comparative protein structure models and associated resources. Nucleic Acids Res 2006, 34:D29I-295.

4. LaCount DJ, Vignali M, Chettier R, Phansalkar A, Bell R, Hesselberth JR, Schoenfeld LW, Ota I, Sahasrabudhe S, Kurschner C, et al.: A protein interaction network of the malaria parasite Plasmodium falciparum. Nature 2005, 438: 103-107.

Publish with Bio Med Central and every scientist can read your work free of charge

"BioMed Central will be the most significant development for disseminating the results of biomedical research in our lifetime. "

Sir Paul Nurse, Cancer Research UK

Your research papers will be:

- available free of charge to the entire biomedical community

- peer reviewed and published immediately upon acceptance

- cited in PubMed and archived on PubMed Central

- yours - you keep the copyright

Submit your manuscript here:

http://www.biomedcentral.com/info/publishing_adv.asp 